\title{
PENERAPAN MODEL PEMBELAJARAN KOOPERATIF TIPE NUMBERED HEADS TOGETHER BERBANTUAN MEDIA INTERAKTIF UNTUK MENINGKATKAN AKTIVITAS DAN PRESTASI BELAJAR SISWA
}

\author{
Agni Era Hapsari \\ agniera.hapsari@staff.uksw.edu \\ Progam Studi Pendidikan Sejarah UKSW
}

\begin{abstract}
Implementation Of Cooperative Learning Model Numbered Heads Together Aided Interactive Media To Increase Students Activities And Learning Achievement
\end{abstract}

This study aimed to improve history learning achievement through the implementation of cooperative learning model NHT assisted interactive media. The method used in this research was a classroom action research by conducting two meetings in two cycles. The instrument used was questionnaire for the interview and questionnaire for observation of learning activities and achievement test. Data analysis techniques used was comparative descriptive method by comparing pre cycle and between cycles. The results of the study in the first cycle was the activity of 12 students or $40 \%$ in the high category, activity 9 students or 30\% was in medium category and the activity of another 9 students or $30 \%$ was in lower categories. It was found that 24 students or $70 \%$ were mastery learning with average grade 62.25. In the second cycle, the activity of 24 students or $80 \%$ was in higher category, activity of 6 students or $20 \%$ was in medium category, and 0 student or $0 \%$ in lower categories. The average of learning achievement reached 85 with 30 students mastery learning or 100\%. Based on the analysis and discussion of the research, it is concluded that the implementation of cooperative learning model NHT aided interactive media can improve student achievement.

Keywords: NHT, Instructional Media, Learning Activity and Achievement

\section{PENDAHULUAN}

Peraturan Mendiknas No. 22 Tahun 2006 Standar Isi untuk Satuan Pendidikan Dasar dan Menengah (Aman, 2011: 58) menyebutkan bahwa mata pelajaran sejarah secara rinci memiliki tujuan menumbuhkan kesadaran kesadaran dalam diri peserta didik sebagai bagian dari bangsa Indonesia yang memiliki rasa bangga dan cinta tanah air yang dapat diimplementasikan dalam berbagai bidang kehidupan baik nasional maupun internasional.

Sejarah mengandung arti suatu ilmu pengetahuan yang mempelajari segala peristiwa atau kejadian yang telah terjadi pada masa lampau dalam kehidupan umat manusia. Menurut Kuntowijoyo (2005: 18) sejarah adalah rekonstruksi masa lalu. Seorang guru memiliki peran yang sangat besar dalam mengorganisasikan kelas sebagai bagian dari proses pembelajaran dan siswa sebagai subjek yang sedang belajar. Akan tetapi pembelajaran sejarah yang kedudukannya sebagai mata pelajaran pembangun karakter dan sikap nasionalisme siswa 
Penerapan Model Pembelajaran Kooperatif Tipe Numbered Heads Together Berbantuan Media Interaktif untuk Meningkatkan Aktivitas dan Prestasi Belajar Siswa (Agni Era Hapsari)

pada kedudukannya mulai dianggap kurang penting. Sering kita jumpai jika anak ditanya pelajaran apa yang paling tidak disukai jawabannya adalah sejarah, pelajaran apa yang paling membosankan adalah sejarah, guru apa yang paling tidak disukai adalah guru sejarah dan sebagainya. Maka berdasarkan fenomena tersebut dari sekian rangkaian proses pembelajaran sejarah jelas ada sesuatu yang salah, pengamatan kami terhadap proses pembelajaran sejarah pada siswa SMA, ditemukan data bahwa sebagian siswa memiliki motivasi dan kompetensi belajar yang rendah. Pelaksanaan kegiatan belajar mengajar sejarah belum dapat berjalan secara maksimal karena dipengaruhi beberapa faktor, antara lain: 1) tuntutan materi pelajaran yang cukup padat dan alokasi waktu yang terbatas, membuat guru lebih mementingkan mengejar materi, 2) proses kegiatan pembelajaran yang monoton dengan menempatkan guru sebagai sumber belajar berdampak pada kebosanan siswa dalam proses pembelajaran, 3) guru kurang memanfaatkan penggunaan media pembelajaran disebabkan mereka belum mengetahui keuntungan/manfaat yang diperoleh dengan menggunakan media dalam pelaksanaan proses belajar mengajar.

Berdasarkan pada permasalahan tersebut dalam rangka untuk meningkatkan hasil belajar siswa kelas XI IPS SMA N 1 Tuntang, maka diperlukan upaya untuk memilih dan menggunakan model, metode, dan strategi pembelajaran dengan disertai juga pemilihan media pembelajaran yang sesuai dengan karakter peserta didik. Adapun upaya untuk tercapainya peningkatan hasil belajar siswa tersebut adalah menerapkan model pembelajaran kooperatif tipe NHT (Numbered Heads Together) dalam pembelajaran Sejarah. Dalam model NHT pada proses pelaksanaan pembelajaran menitik beratkan pada adanya kemampuan berfikir dalam memecahkan suatu masalah dalam diskusi kelompok. Ada beberapa manfaat pada model pembelajaran kooperatif tipe NHT terhadap siswa yang hasil belajar rendah yang dikemukakan oleh Lundgren (dalam Ibrahim, 2000: 18), antara lain adalah: rasa harga diri menjadi lebih tinggi, memperbaiki kehadiran, penerimaan terhadap individu menjadi lebih besar, perilaku mengganggu menjadi lebih kecil, konflik antara pribadi berkurang, pemahaman yang lebih mendalam, meningkatkan kebaikan budi, kepekaan dan toleransi, hasil belajar lebih tinggi.

Tujuan dari penelitian ini adalah untuk meningkatkan aktivitas dan prestasi belajar mata pelajaran sejarah melalui penerapan model pembelajaran kooperatif tipe NHT berbantuan media interaktif pada siswa kelas XI IPS SMA N 1 Tuntang semester 2 tahun pelajaran 2015/2016.

\section{KAJIAN PUSTAKA}

\section{Aktivitas Belajar Siswa}

Anak yang belajar selalu melakukan aktivitas. Aktivitas siswa selama proses pembelajaran merupakan salah satu indikator adanya keinginan siswa untuk belajar. Reber (Syah, 2004: 109) mengemukakan bahwa aktivitas adalah proses yang berarti cara-cara atau langkah-langkah khusus yang dengan beberapa perubahan ditimbulkan hingga tercapainya hasil-hasil tertentu.

Menurut Sardiman (2011: 100) aktivitas belajar merupakan prinsip atau azas yang sangat penting didalam interaksi belajar-mengajar. Aktivitas yang dimaksud disini bukan hanya aktivitas fisik tetapi mencakup aktivitas mental. Pada kegiatan belajar, kedua aktivitas tersebut saling berkait. Aktivitas fisik adalah peserta didik giat aktif dengan anggota badan, membuat sesuatu, beriman ataupun bekerja, ia tidak hanya duduk dan mendengarkan, melihat atau hanya pasif. Peserta didik yang mempunyai aktivitas psikis adalah jika daya jiwanya bekerja sebanyak-banyaknya dalam rangka pembelajaran. Seluruh peranan dan kemauan dikerahkan dan diarahkan supaya daya itu tetap aktif untuk mendapatkan hasil pengajaran yang optimal. 


\section{Prestasi Belajar}

Nana Sudjana (2005: 5) berpendapat belajar adalah suatu proses yang ditandai dengan adanya perubahan pada diri seseorang. Perubahan sebagai hasil dari proses belajar dapat ditunjukkan dalam berbagai bentuk seperti perubahan pengetahuan, sikap dan tingkah laku, keterampilan, kecakapan, kebiasaan serta perubahan aspek-aspek lain yang ada pada individu yang belajar.

Prestasi belajar adalah suatu hasil usaha yang telah dicapai oleh siswa yang mengadakan suatu kegiatan belajar di sekolah dan usaha yang dapat menghasilkan perubahan pengetahuan, sikap dan tingkah laku. Hasil perubahan tersebut diwujudkan dengan nilai atau skor (Winkel, 2005: 532). Muhibin Syah (2004: 141) menjelaskan prestasi belajar adalah setiap macam kegiatan belajar menghasilkan suatu perubahan yang khas yaitu hasil belajar. Menurut Lukman Ali (2005: 768) dikatakan bahwa prestasi belajar adalah hasil usaha yang telah dicapai atau yang telah dikerjakan untuk mendapatkan suatu kecakapan dan kepandaian.

Berdasarkan beberapa pendapat di atas, maka dalam penelitian ini yang dimaksud prestasi belajar adalah suatu hasil usaha yang telah dicapai oleh siswa baik penguasaan pengetahuan atau keterampilan sebagai hasil belajar yang ditunjukkan dengan nilai atau angka yang diberikan oleh guru. Prestasi dalam penelitian dimaksudkan adalah nilai yang diperoleh siswa pada mata pelajaran sejarah yang berupa angka yang diberikan oleh guru setelah melakukan tugas yang diberikan oleh guru kepada siswa.

\section{Model Pembelajaran Kooperatif Tipe NHT}

Model pembelajaran merupakan pola yang digunakan sebagai pedoman dalam merencanakan pembelajaran di kelas, termasuk di dalamnya penyusunan kurikulum, mengatur materi, menentukan tujuan-tujuan pembelajaran, menentukan tahap-tahap dalam kegiatan pembelajaran, lingkungan pembelajaran, dan pengelolaan kelas.

Isjoni (2010: 20) menjelaskan bahwa pembelajaran kooperatif adalah pembelajaran yang menggunakan kelompok-kelompok kecil sehingga siswa-siswa saling bekerja sama untuk mencapai tujuan pembelajaran. Pembelajaran kooperatif juga mengkondisikan siswa untuk aktif dan saling member dukungan dalam kerja kelompok untuk menuntaskan materi masalah dalam belajar. Trianto (2010: 63) menyebutkan dalam model pembelajaran kooperatif terdapat beberapa variasi atau tipe model yang dapat diterapkan, salah satu diantaranya adalah tipe NHT (Numbered Heads Together). NHT pertama kali dikembangkan oleh Spencer Kagen pada tahun 1993 untuk menelaah materi pelajaran dan mengecek pemahaman mereka terhadap isi pelajaran tersebut. NHT atau penomoran berpikir bersama merupakan tipe pembelajaran kooperatif yang dirancang untuk mempengaruhi pola interaksi siswa sebagai alternatif terhadap struktur kelas tradisional.

Suprijono (2011: 92) berpendapat bahwa model NHT (Numbered Heads Together) adalah model pembelajaran yang diawali dengan Numbering yaitu guru membagi kelompok dan tiap orang dalam tiap kelompok diberi nomor. Kemudian guru mengajukan beberapa pertanyaan dan pada kesempatan ini tiap kelompok menyatukan kepalanya "Heads Together" berdiskusi memikirkan jawabannya. Selanjutnya guru memanggil siswa yang memiliki nomor yang sama dari tiap kelompok dan mendiskusikan jawaban yang paling tepat.

NHT juga banyak sekali digunakan sebagai bahan penelitian tindakan kelas (PTK) karena NHT lebih mengedepankan kepada aktivitas siswa dalam mencari, mengolah, dan melaporkan informasi dari berbagai sumber yang akhirnya dipresentasikan di depan kelas sehingga dapat melatih siswa untuk saling berbagi informasi, mendengarkan dengan cermat serta berbicara dengan penuh perhitungan, sehingga siswa lebih produktif dalam pembelajaran. Terdapat empat langkah 
Penerapan Model Pembelajaran Kooperatif Tipe Numbered Heads Together Berbantuan Media Interaktif untuk Meningkatkan Aktivitas dan Prestasi Belajar Siswa (Agni Era Hapsari)

yang dapat dilakukan dalam proses pembelajaran dengan teknik Numbered Heads Together adalah berikut ini:

Tabel 1. Langkah-langkah Teknik Numbered Heads Together

\begin{tabular}{ll}
\hline No. Langkah-langkah & Aktifitas Siswa \\
\hline $\begin{array}{l}\text { 1. Penomoran } \\
\text { (Numbered })\end{array}$ & $\begin{array}{l}\text { Guru membagi para siswa menjadi beberapa kelompok atau tim yang } \\
\text { beranggotakan 3-5 orang dan memberi nomor sehingga tiap siswa dalam } \\
\text { tim memiliki nomor yang berbeda }\end{array}$ \\
\hline $\begin{array}{l}\text { 2. Pengajuan } \\
\begin{array}{l}\text { Pertanyaan } \\
\text { Questioning) }\end{array}\end{array}$ & $\begin{array}{l}\text { Guru mengajukan pertanyaan kepada siswa dan pertanyaan ini } \\
\text { bervariasi mulai dari yang spesifik sampai ke hal-hal yang bersifat umum }\end{array}$ \\
\hline 3. Berfikir Bersama & $\begin{array}{l}\text { Menggambarkan dan meyakinkan bahwa setiap anggota kelompok } \\
\text { (Heads Together })\end{array}$ \\
\hline $\begin{array}{l}\text { mengetahui jawaban tersebut } \\
\text { Pemberian Jawaban Guru menyebut satu nomor dan para siswa dari tiap kelompok dengan } \\
\text { (Answering) }\end{array}$ & $\begin{array}{l}\text { nomor yang sama mengangkat tangan dan menyiapkan jawaban untuk } \\
\text { seluruh kelas }\end{array}$ \\
\hline
\end{tabular}

Beberapa manfaat pada model pembelajaran kooperatif tipe NHT terhadap siswa yang hasil belajar rendah yang dikemukakan oleh Lundgren (dalam Ibrahim, 2000: 18), antara lain adalah: rasa harga diri menjadi lebih tinggi, memperbaiki kehadiran, penerimaan terhadap individu menjadi lebih besar, perilaku mengganggu menjadi lebih kecil, konflik antara pribadi berkurang, pemahaman yang lebih mendalam, meningkatkan kebaikan budi, kepekaan dan toleransi, hasil belajar lebih tinggi.

Sehingga berdasarkan pengertian di atas bahwa NHT adalah bagian dari model pembelajaran kooperatif struktural, yang menekankan pada struktur-struktur khusus yang dirancang untuk mempengaruhi pola interaksi siswa yang lebih mengedepankan kepada aktivitas siswa dalam mencari, mengolah, dan melaporkan informasi dari berbagai sumber yang akhirnya dipresentasikan di depan kelas sehingga dapat melatih siswa untuk saling berbagi informasi, mendengarkan dengan cermat serta berbicara dengan penuh perhitungan, sehingga siswa lebih produktif dalam pembelajaran.

\section{Media Pembelajaran}

Kata media pembelajaran berasal dari bahasa Latin yang merupakan bentuk jamak dari kata medium yang secara harfiah berarti 'perantara' atau pengantar (Arief S. Sadiman, dkk, $2006: 6$ ). Banyak pakar tentang media pembelajaran yang memberikan batasan tentang pengertian media. Menurut Rohani (1997: 2) media adalah segala bentuk yang dipergunakan untuk proses penyaluran informasi.

Media adalah segala sesuatu yang dapat digunakan untuk menyalurkan pesan dari pengirim ke penerima sehingga dapat merangsang pikiran, perasaan, perhatian dan minat siswa sedemikian rupa sehingga terjadi proses belajar (Purnamawati dan Eldarni, 2001: 4).

Penggunaan media pembelajaran dapat mempertinggi proses dan hasil pengajaran adalah berkenaan dengan taraf berfikir siswa. Taraf berfikir manusia mengikuti tahap perkembangan dimulai dari berfikir konkrit menuju berfikir abstrak, dimulai dari berfikir sederhana menuju ke pola berfikir kompleks. Penggunaan media erat kaitannya dengan tahapan berfikir tersebut karena melalui media pembelajaran hal-hal yang abstrak dapat dikonkretkan, dan hal-hal yang kompleks dapat disederhanakan (Rivai, 1991: 2). 
Ada beberapa jenis media pembelajaran yang biasa digunakan dalam proses belajar mengajar. Pertama, media grafis seperti gambar, foto, grafik bagan atau diagram, poster, kartun, komik dan lainlain. Media grafis sering juga disebut media dua dimensi, yakni media yang mempunyai ukuran panjang dan lebar. Kedua, media tiga dimensi yaitu dalam betuk model seperti model padat (solid model), model penampang, model susun, model kerja, mock up, diorama dan lain-lain. Ketiga, media proyeksi seperti slide, film strips, film, penggunaan OHP dan lain-lain. Keempat penggunaan lingkungan sebagai media pengajaran (Rivai, 1991:5).

Asyhar (2011: 44-45) mengelompokkan jenis-jenis media pembelajaran menjadi empat, yaitu:

a. Media visual yaitu jenis media yang digunakan hanya mengandalkan indera penglihatan, misalnya media cetak seperti buku, jurnal, peta, gambar, dan lain sebagainya.

b. Media audio adalah jenis media yang digunakan hanya mengandalkan pendengaran saja. Contohnya tape recorder, dan radio.

c. Media audio visual adalah jenis media yang dalam penggunaannya melibatkan indra pendengaran dan indra penglihatan sekaligus. Contohnya film, video, program TV, dan lain sebagainya.

d. Multimedia yaitu media yang melibatkan beberapa jenis media dan peralatan secara terintegrasi dalam suatu proses atau kegiatan pembelajaran. Berdasarkan beberapa jenis-jenis media pembelajaran tersebut yang akan digunakan dalam penelitian tindakan kelas dengan model kooperatif tipe NHT ini, yaitu media interaktif yang termasuk dalam multimedia. Media ini dipilih karena dengan media interaktif, anak tidak akan merasa jenuh, menarik perhatian siswa agar lebih aktif dalam proses pembelajaran serta memperjelas suatu masalah sehingga siswa akan mudah dalam memahaminya. Jadi dapat disimpulkan dengan media pembelajaran akan memudahkan dalam proses kegiatan pembelajaran sehingga tujuan dari pembelajaran dapat dicapai.

\section{METODE}

Penelitian ini menggunakan jenis Penelitian Tindakan Kelas (PTK). Menurut Arikunto (2010: 2) menyebutkan pengertian PTK dengan menggabungkan batasan pengertian tiga kata inti, yaitu (1) penelitian, (2) tindakan, dan (3) kelas yaitu penelitian tindakan kelas merupakan suatu pencermatan terhadap kegiatan pembelajaran berupa sebuah tindakan, yang sengaja dimunculkan dan terjadi dalam sebuah kelas secara bersama. Penelitian ini dimaksudkan untuk mengungkapkan permasalahan dalam pembelajaran sejarah melalui model pembelajaran NHT (Numbered Heads Together) yang memfokuskan pada interaksi siswa dalam pembelajaran agar dapat meningkatkan hasil belajar peserta didik.

\section{Subjek dan Seting Penelitian}

Subjek dalam penelitian ini adalah siswa kelas XI IPS SMA N 1 Tuntang sejumlah 30 siswa. Penelitian ini dilaksanakan pada semester II tahun ajaran 2015/2016.

Prosedur penelitian yang diterapkan dalam penelitian ini berdasarkan pada penelitian tindakan kelas (PTK). Pelaksanaan penelitian ini dibagi menjadi beberapa siklus. Setiap siklus terdiri atas empat tahapan antara lain: (a) perencanaan, (b) pelaksanaan tindakan, (c) observasi, (d) refleksi.

\section{Teknik Pengumpulan Data}

Dalam penelitian ini, untuk mengumpulkan data selama proses pembelajaran peneliti menggunakan alat pengumpulan data berupa: (1) Pedoman wawancara, yang digunakan untuk 
Penerapan Model Pembelajaran Kooperatif Tipe Numbered Heads Together Berbantuan Media Interaktif untuk Meningkatkan Aktivitas dan Prestasi Belajar Siswa (Agni Era Hapsari)

mengetahui kendala yang dihadapi siswa dan guru dalam pelaksanaan pembelajaran. (2) Lembar observasi, digunakan untuk mengukur aktivitas siswa. (3) Tes, digunakan untuk mengukur hasil belajar siswa, dan (4) teknik dokumentasi.

Dalam hal ini, peneliti menggunakan teknik analisis data dengan cara deskriptif kualitatif dan kuantitatif. Deskriptif kualitatif maksudnya adalah dalam penelitian ini hanya menggambarkan objek permasalahan untuk mencapai kejelasan masalah yang dibahas, sehingga dapat diketahui apakah ada penyimpangan-penyimpangan atau sudah sesuai dengan teori-teori yang ada, selanjutnya dipergunakan sebagai dasar untuk membahas permasalahan dalam penelitian ini. Sedangkan deskriptif kuantitatif maksudnya adalah dalam pembahasan juga diuraikan hasil yang dicapai dalam bentuk data numerik (data yang berupa angka). Adapun teknik analisis data dengan cara deskriptif kualitatif meliputi data kendala-kendala yang dihadapi siswa dan guru dalam penerapan pembelajaran Sejarah dengan menggunakan model pembelajaran kooperatif tipe NHT.

Adapun teknik analisis data dengan cara kualitatif meliputi analisis hasil belajar siswa, analisis aktivitas siswa. Teknik analisis data terhadap permasalahan tersebut meliputi beberapa tahapan, yaitu tahap pengumpulan data, reduksi data, penyajian data, dan penyimpulan data.

Indikator keberhasilan yang dipergunakan pada penelitian ini jika keterlaksanaan aktivitas siswa dalam kegiatan pembelajaran mencapai persentase keberhasilan sebesar $80 \%$, dan siswa dinyatakan tuntas apabila telah memperoleh nilai sesuai dengan KKM yang telah ditentukan sebesar 75, Jadi nilai hasil belajar kognitif siswa harus $\geq 75$. Sedangkan ketuntasan belajar klasikal dapat dikatakan tercapai apabila paling sedikit $80 \%$ siswa di kelas tersebut telah mencapai ketuntasan belajar.

\section{HASIL DAN PEMBAHASAN \\ Kondisi Awal}

Pembelajaran mata pelajaran Sejarah yang dilakukan di SMA N 1 Tuntang selama ini dianggap sebagai pelajaran hafalan semata, guru menganggap mudah, sehingga guru hanya berceramah di depan kelas. Dalam pembelajaran sejarah sering kali hanya gurulah yang aktif, sedangkan siswanya pasif hanya duduk mendengarkan ceramah. Pembelajaran yang demikian mengakibatkan kebanyakan siswa ada yang mengantuk, bermain sendiri, dan suka rebut sendiri. Di samping itu aktivitas dan minat belajar siswa pada mata pelajaran Sejarah juga rendah, sehingga menambah rendah pula tingkat pemahaman siswa terhadap materi yang diajarkan. Kondisi proses pembelajaran ini berakibat aktivitas belajar siswa rendah. Hal ini ditunjukkan hasil pengamatan dari 30 siswa hanya 6 siswa atau 20\% yang aktivitas tinggi, 6 siswa atau 20\% aktivitas sedang, dan 18 siswa atau $60 \%$ aktivitas rendah.

Kondisi rendahnya aktivitas siswa berdampak juga pada rendahnya prestasi belajar. Hal ini ditunjukkan dari hasil tes prestasi belajar Sejarah pada akhir materi nilai rata-rata yaitu 62,25. Dari nilai tes prestasi belajar pra siklus menunjukkan banyak siswa yang belum tuntas. Siswa yang mendapatkan nilai lebih besar atau sama dengan KKM yaitu 75 ada 6 orang dengan ketuntasan 20\%. Nialai tertinggi 80, sedangkan nilai terendah 50 dengan rentang nilai $0-100$ dengan nilai rata-rata 62,25 .

\section{Siklus I}

\section{Aktivitas Belajar}

Data tentang aktivitas belajar diambil setelah melakukan pembelajaran pada akhir siklus I, Instrumen data berupa lembar pengamatan yang terdiri dari 10 indikator. Dari data diperoleh aktivitas skor 1-3 kategori rendah, aktivitas skor 4-7 kategori sedang, aktivitas skor 8-10 kategori tinggi. Hasil pengamatan diperoleh hasil aktivitas belajar sebagai berikut : skor tinggi 12 siswa 
atau 40\%, skor sedang 9 siswa atau 30\%, dan skor rendah 9 siswa atau 30\%.

\section{Prestasi Belajar}

Setelah pembelajaran berlangsung selama 3 kali pertemuan maka dilakukan tes tertulis mata pelajaran Sejarah. Hasil tes prestasi belajar Sejarah diperoleh hasil sebagai berikut : nilai tertinggi 85, nilai terendah 60, nilai rata-rata 70. Masih ada 9 siswa (30\%) yang mendapat nilai di bawah ketuntasan belajar minimal (KKM). Hasil analisis tes prestasi belajar Sejarah diperoleh rerata 70, nilai tertinggi 85 nilai terendah 60 ketuntasan belajar 21 siswa atau $70 \%$.

\section{Siklus II}

\section{Aktivitas Belajar Siswa}

Data tentang aktivitas belajar diambil setelah melakukan pembelajaran pada akhir siklus II, Instrumen data berupa lembar pengamatan yang terdiri dari 10 indikator. Dari data diperoleh aktivitas skor tinggi 24 siswa atau $80 \%$, skor sedang 6 siswa atau $20 \%$, dan skor rendah 0 siswa atau $0 \%$.

\section{Tes Prestasi Belajar}

Setelah pembelajaran berlangsung selama 3 kali pada siklus II maka dilakukan tes tertulis mata pelajaran Sejarah. Hasil tes prestasi belajar Sejarah diperoleh hasil sebagai berikut : nilai tertinggi 95, nilai terendah 77, nilai rerata 85 dengan ketuntasan belajar 30 siswa atau $100 \%$.

\section{Komparasi Hasil Penelitian}

Perbandingan hasil penelitian pra siklus, siklus I, siklus II setelah dilakukan pengamatan saat proses pembelajaran diperoleh data sebagai berikut :

Tabel 2. Perbandingan Aktivitas Belajar Siswa Pra Siklus, Siklus I, dan Siklus II

\begin{tabular}{cllll}
\hline No & $\begin{array}{c}\text { Aktivitas } \\
\text { Belajar Siswa }\end{array}$ & \multicolumn{1}{c}{ Pra Siklus } & \multicolumn{1}{c}{ Siklus 1 } & \multicolumn{1}{c}{ Siklus 2 } \\
\hline 1. & Tinggi & 6 siswa $(20 \%)$ & 12 siswa (40\%) & 24 siswa (80\%) \\
\hline 2. & Sedang & 6 siswa $(20 \%)$ & 9 siswa $(30 \%)$ & 6 siswa (20\%) \\
\hline 3. & Rendah & 18siswa (60\%) & 9 siswa (30\%) & 0 siswa (0\%) \\
\hline
\end{tabular}

Berdasarkan data di atas pada siklus I ada kenaikan aktivitas belajar siswa yang tinggi dari 6 siswa pada pra siklus menjadi 12 siswa pada siklus I. Pada siklus II ada kenaikan aktivitas yang tinggi dari 12 siswa pada siklus I menjadi 24 siswa pada siklus II. Hal ini dapat disimpulkan bahwa pembelajaran dengan model NHT berbantuan media interaktif dapat meningkatkan aktivitas belajar yang tinggi dari 6 siswa pada pra siklus menjadi 24 siswa pada siklus II.

Perbandingan hasil tes prestasi belajar pra siklus, siklus I, dan siklus II setelah dilakukan ulangan pada akhir siklus diperoleh data sebagai berikut :

Tabel 3. Perbandingan Prestasi Belajar Sejarah Pra Siklus, Siklus I, dan Siklus II

\begin{tabular}{|c|c|c|c|c|}
\hline No & Prestasi Belajar Sejarah & Pra Siklus & Siklus I & Siklus II \\
\hline 1. & Nilai Tertinggi & 80 & 85 & 95 \\
\hline 2. & Nilai Terendah & 50 & 70 & 77 \\
\hline 3. & Nilai Rata-rata & 62,25 & 70 & 85 \\
\hline 4. & Ketuntasan Belajar & $20 \%$ & $70 \%$ & $100 \%$ \\
\hline
\end{tabular}

Pada tabel diatas terlihat pra siklus nilai rata-rata 62,25 , pada siklus I rata-rata 70 dan siklus II rata-rata 85. Dengan demikian pembelajaran dengan model pembelajaran NHT berbantuan media interaktif dapat meningkatkan prestasi belajar Sejarah. Ketuntasan belajar pada 
Penerapan Model Pembelajaran Kooperatif Tipe Numbered Heads Together Berbantuan Media Interaktif untuk Meningkatkan Aktivitas dan Prestasi Belajar Siswa (Agni Era Hapsari)

pra siklus 20\%, pada siklus I $70 \%$, dan siklus II 100\%. Ini berarti pada siklus I ada peningkatan ketuntasan belajar $50 \%$ yakni dari pra siklus $20 \%$ menjadi $70 \%$. Sedangkan pada siklus II ada peningkatan ketuntasan belajar 30\% yakni dari siklus I $70 \%$ menjadi $100 \%$. Pembelajaran dengan menerapkan model pembelajaran NHT berbantuan media interaktif dapat meningkatkan ketuntasan belajar $20 \%$ dari pra siklus menjadi $100 \%$ pada siklus II.

\section{Pembahasan}

Prestasi belajar pada mata pelajaran Sejarah yang diukur melalui tes prestasi menunjukkan hasil pada pra siklus rerata 62,25 dan ketuntasan $20 \%$. Setelah dilakukan pembelajaran dengan menggunakan model pembelajaran NHT berbantuan media interaktif ada peningkatan. Pada siklus I rerata 70 dan ketuntasan 70\%. Dari hasil refleksi hasil tersebut masih belum mencapai indikator keberhasilan. Dengan memperbaiki kekurangan yang ada pada siklus I yaitu membagi kelompok dengan susunan yang lebih merata kemampuannya dan lebih mempersiapkan seluruh bahan dan sumber belajar serta memperjelas cara penggunaan media interaktif, maka hasil tes prestasi pada siklus II rerata 85 dengan ketuntasan $100 \%$.

Penerapan model pembelajaran NHT berbantuan media interaktif berdampak pada situasi kelas dan siswa. Perubahan kondisi siswa antara lain siswa aktif, berani melakukan presentasi, dan suasana pembelajaran menjadi menyenangkan. Pada siklus II proses pembelajaran menjadi lebih baik karena penerapan model pembelajaran NHT berbantuan media interaktif dapat meningkatkan aktivitas siswa melalui diskusi kelompok sebagaimana pendapat Syaiful Bahri Djamarah (2002: 99) mengatakan teknik diskusi merupakan teknik belajar mengajar yang dilakukan oleh guru di sekolah. Di dalam diskusi ini proses belajar mengajar terjadi, dimana interaksi antara dua atau lebih individu yang terlibat, saling tukar menukar pengalaman, informasi, memecahkan masalah dapat terjadi dan semua aktif. Sedangkan penggunaan media interaktif pembelajaran dapat mempertinggi proses dan hasil pengajaran adalah berkenaan dengan taraf berfikir siswa. Taraf berfikir manusia mengikuti tahap perkembangan dimulai dari berfikir konkrit menuju berfikir abstrak, dimulai dari berfikir sederhana menuju kepola berfikir kompleks. Penggunaan media erat kaitannya dengan tahapan berfikir tersebut karena melalui media pembelajaran hal-hal yang abstrak dapat dikonkretkan, dan hal-hal yang kompleks dapat disederhanakan (Rivai, 1991: 2). Kelebihan penerapan model pembelajaran NHT berbantuan media interaktif dalam pembelajaran Sejarah antara lain: 1) memotivasi dan menarik keingin tahuan siswa untuk belajar Sejarah, 2) merangsang kreativitas siswa dalam bentuk ide, gagasan, dan trobosan baru dalam memecahkan masalah, dan 3) meningkatkan aktivitas belajar siswa.

Dari uraian di atas maka dapat diperoleh hasil penelitian bahwa penerapan model pembelajaran NHT berbantuan media interaktif dapat meningkatkan aktivitas belajar yang kategori tinggi dari $20 \%$ atau 6 siswa pada pra siklus, menjadi $100 \%$ atau 30 siswa pada siklus II, dan dapat meningkatkan prestasi belajar rata-rata 62,25 pada pra siklus menjadi 85 pada siklus II dengan ketuntasan belajar dari $20 \%$ atau 6 siswa pada pra siklus menjadi $100 \%$ atau 30 siswa pada siklus II.

\section{PENUTUP}

\section{Simpulan}

Berdasarkan hasil pembahasan di atas, maka dapat disimpulkan bahwa penerapan model pembelajaran kooperatif tipe NHT (Numbered Heads Together) berbantuan media pembelajaran interaktif dapat meningkatkan aktivitas dan prestasi belajar pada siswa kelas XI IPS SMA N 1 Tuntang pada semester 2 tahun ajaran 2015/2016.

\section{Saran}


Berdasarkan hasil penelitian yang telah dilakukan, diketahui bahwa penerapan model pembelajaran kooperatif tipe NHT berbantuan media pembelajaran interaktif dapat meningkatkan aktivitas dan prestasi belajar siswa pada mata pelajaran Sejarah. Oleh karena itu penulis menyarankan: (1) kepada para guru agar lebih dapat mengembangkan pembelajaran dengan menerapkan model pembelajaran kooperatif tipe NHT berbantuan media pembelajaran interaktif agar anak lebih termotivasi untuk belajar sehingga dapat meningkatkan prestasi belajar yang dicapai siswa, (2) pihak sekolah juga harus berperan serta dengan memberikan fasilitas yang memadai untuk berlangsungnya pembelajaran dengan menggunakan model pembelajaran kooperatif tipe NHT berbantuan media pembelajaran interaktif.

\section{DAFTAR PUSTAKA}

Abdul Munib, dkk. 2009. Pengantar Ilmu Pendidikan. Semarang: UNNES Press.

Agus Suprijono. 2011. Model-Model Pembelajaran. Jakarta: Gramedia Pustaka Jaya.

Ahmad Rohani 1997. Media Intruksional Edukatif. Jakarta: Rineka Cipta

Ahmad Sabri. 2005. Strategi Belajar Mengajar dan Micro Teaching. Jakarta: Quantum Teaching

Aman. 2011. Model Evaluasi Pembelajaran Sejarah. Yogyakarta: Ombak

Arif S. Sadiman, dkk. 2006. Media Pendidikan. Jakarta: Rajawali Pers

Arikunto, Suharsimi. 2010. Penelitian Tindakan Kelas Untuk Guru, Kepala Sekolah dan Pengawas. Yogyakarta: Aditya Media.

Djamarah, Syaiful Bahri. 2002. Strategi Belajar Mengajar. Jakarta: Rineka Cipta.

Isjoni. 2010. Pembelajaran Kooperatif. Yogyakarta: Pustaka Pelajar.

Kuntowijoyo 2005. Pengantar Ilmu Sejarah. Yogyakarta: Bentang Pustaka

Lukman Ali. 1995. Kamus Besar Bahasa Indonesia. Jakarata: Balai Pustaka

Muhibin Syah. 2004. Psikologi Pendidikan. Bandung: Rosda Karya

Muslimin, Ibrahim. 2000. Pembelajaran Kooperatif. Surabaya: University Press

Nana Sudjana. 2005. Penilaian Hasil Proses Belajar Mengajar. Bandung: PT. Remaja Rosdikarya

Purnamawati dan Eldarni. 2001. Media Pembelajaran. Jakarta: CV. Rajawali.

Rivai, dkk. 1991. Media Pengajaran. Bandung: CV. Sinar Baru

Trianto. 2010. Mendesain Model Pembelajaran Inovatif-progresif. Jakarta: Kencana

Sardiman, A.M. 2001. Interaksi dan Motivasi Belajar Mengajar. Jakarta: Rajawali

Suprijono. 2011. Suprijono, Agus. Cooperative Learning: Teori dan Aplikasi PAIKEM. Yogyakarta: Pustaka Pelajar

Winkel, W.S. 1996. Psikologi Pengajaran. Jakarta: PT. Grasindo. 